\title{
ULTRASTRUCTURAL EVIDENCE OF THE HEPATOTOXIC EFFECT OF HALOTHANE IN RATS FOLLOWING IN-UTERO EXPOSURE
}

\author{
Louis W. Chang, Young K. Lee, Alden W. Dudley, Jr, and Jordan Katz
}

\section{INTRODUCTION}

SiNCE THE Introduction of HALOTHANE for clinical use in $1956,{ }^{1}$ isolated cases of hepatitis following exposure to halothane have been reported in the medical literature $^{2-5}$ suggesting the possible role of halothane in the induction of hepatic injury. The controversy over the existence of halothane hepatitis has been reviewed by various investigators ${ }^{\mathbf{b}-8}$ and halothane hepatitis has been generally accepted as a medical entity. ${ }^{6}$ Recent studies have demonstrated that hepatic lesions similar to those in human cases could be induced in rats ${ }^{9}$ and guinea pigs ${ }^{10}$ after single or repeated exposure to halothane further confirming the hepatotoxicity of halothane.

Increased concern and attention have been aroused towards the possibility that halothane may constitute an occupational hazard for pregnant operating-room personnel. ${ }^{11-15}$ A significantly higher abortion rate was found among anaesthetists and anaesthetic and operating-room nurses ${ }^{12,16-18}$ as compared to general duty nurses and other physicians. No detailed study has been performed to investigate the pathological effects upon adults and foeti following chronic exposure to low concentrations of halothane. The present investigation represents the first detailed report on the pathological changes in the neonatal liver from animals exposed in-utero to halothane. Pathological changes in other organ systems, of either adults or foeti, will be reported elsewhere. ${ }^{19-27}$

\section{Materials ANd Methods}

Sprague-Dawley rats were used in the experiments. After conception eight young female rats were housed in specially designed chambers at the University of Wisconsin Biotron where the environmental conditions could be carefully manipulated. Halothane was introduced to the chambers with the fresh air supply by a Draeger vapourizer. The concentration of halothane was monitored with gas chromatography. The animals were exposed to $10 \mathrm{ppm}$ halothane 8 hours/day and 5 days/week throughout the pregnancy. At term, the pregnant rats were transferred to a halothane-free chamber where the pups were born. An equal number of pregnant rats was used as controls and housed in adjoining halothane-free chambers thoughout pregnancy and delivery.

Four randomly chosen pups from each litter were killed within 24 hours after birth. Tissue samples from the neonatal liver were carefully obtained and fixed in 1 per cent osmium tetroxide for two hours. The tissue samples were then dehy-

From the Departments of Pathology and Anesthesiology, University of Wisconsin, Madison, Wisconsin 53706, USA. 
drated with graded ethanol and embedded in Epon. Thin sections were cut with a DuPont diamond knife on an LKB ultrotome III automatic ultramicrotome. The tissue sections were examined with an RCA EMU-3G electron microscope.

\section{Results}

No ultrastructural or histological changes were observed in the tissue samples from the control pups (Figure 1). However, definitive alterations could be demonstrated in the hepatocytes of pups exposed to halothane.

Myelin-figures (Figure 2) and large areas of focal cytoplasmic degradation (Figure 3) were observed in the cytoplasm of many hepatocytes, indicating cellular injury. Accumulation of lipids within the hepatocytes (Figure 4) and leukocytic infiltration (Figures 5,6) were prominent findings in many liver samples. The infiltrating leukocytes, which consisted mainly of lymphocytes, neutrophils (PMNs) and eosinophils, were largely confined to the hepatic sinusoids (Figures $5,6)$; however, infiltration of the leukocytes into the hepatic parenchyma was also observed (Figure 7). An increase in lysosomal activity (Figure 7) was demonstrable in some hepatocytes.

Focal areas of necrosis (Figure 8) were observed in more than 50 per cent of the tissue samples. Extensive cellular degeneration and cell death were seen in these necrotic areas. Cellular-debris could be found in many Kupffer cells (Figure 9) which were engaged in active phagocytosis.

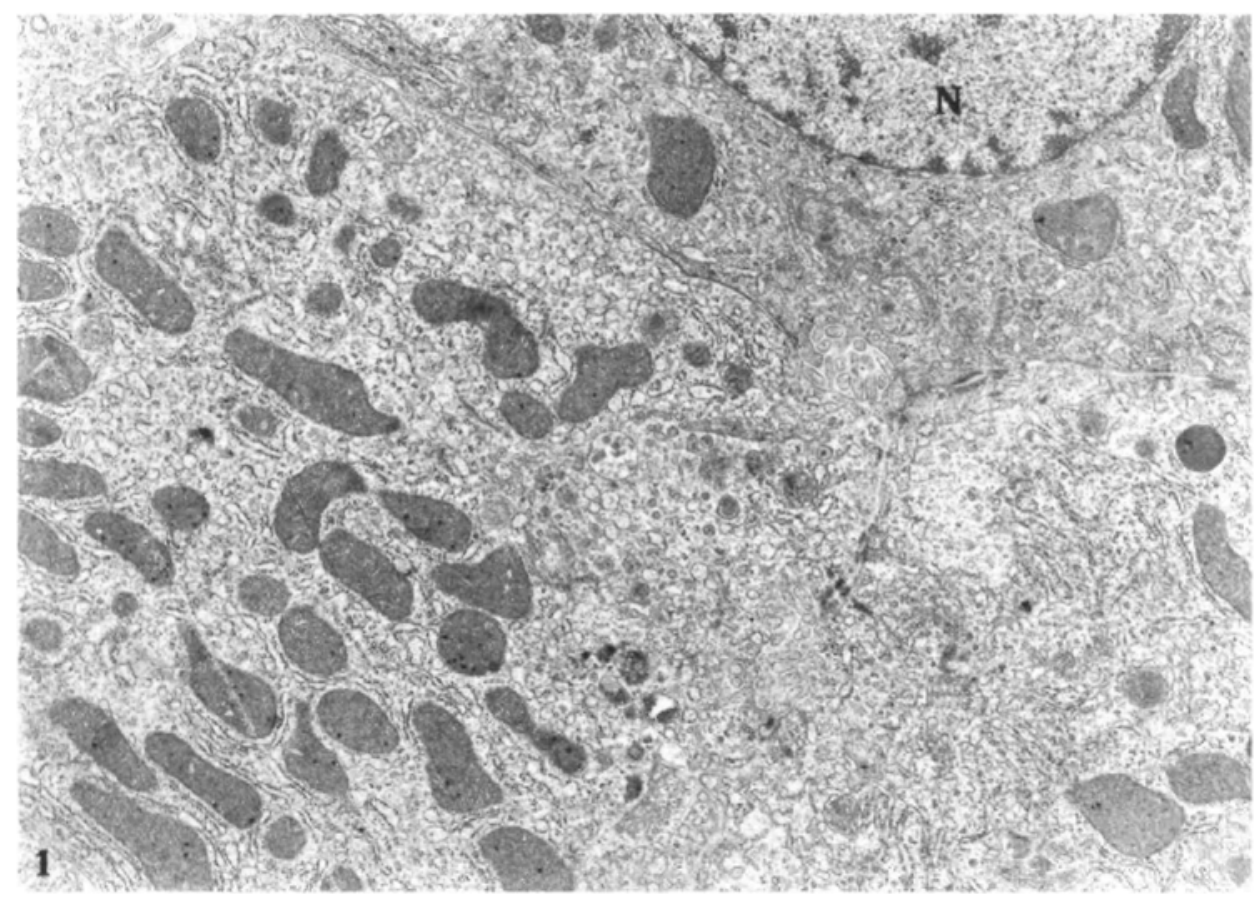

Figure 1, Liver, 24 hours neonatal, normal rat. Nucleus (N). $\times 10,000$. 


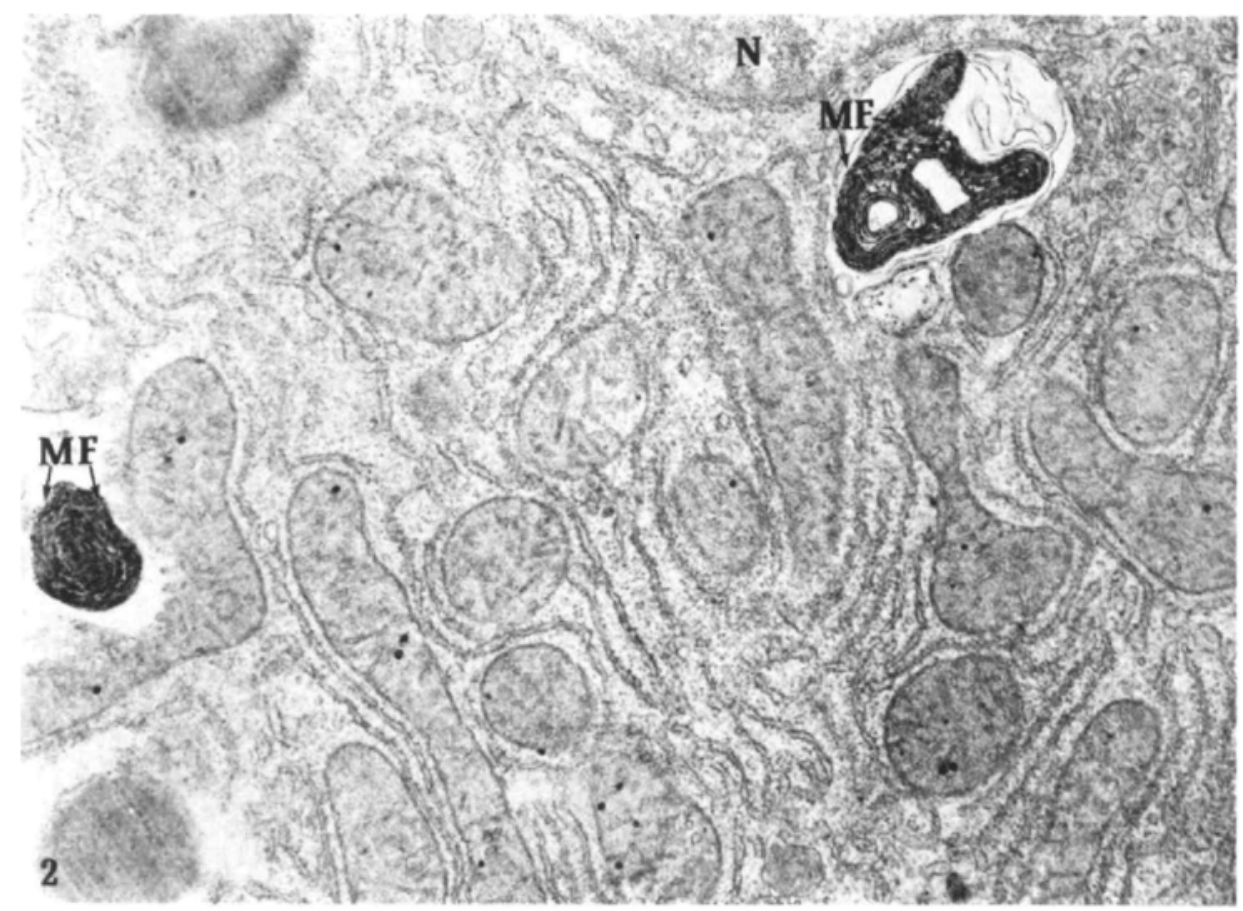

FIGURE 2. Hepatocyte. 24 hours neonatal rat, halothane. Formation of myelin-figures (MF) could be observed. Nucleus $(N) . \times 21,000$.

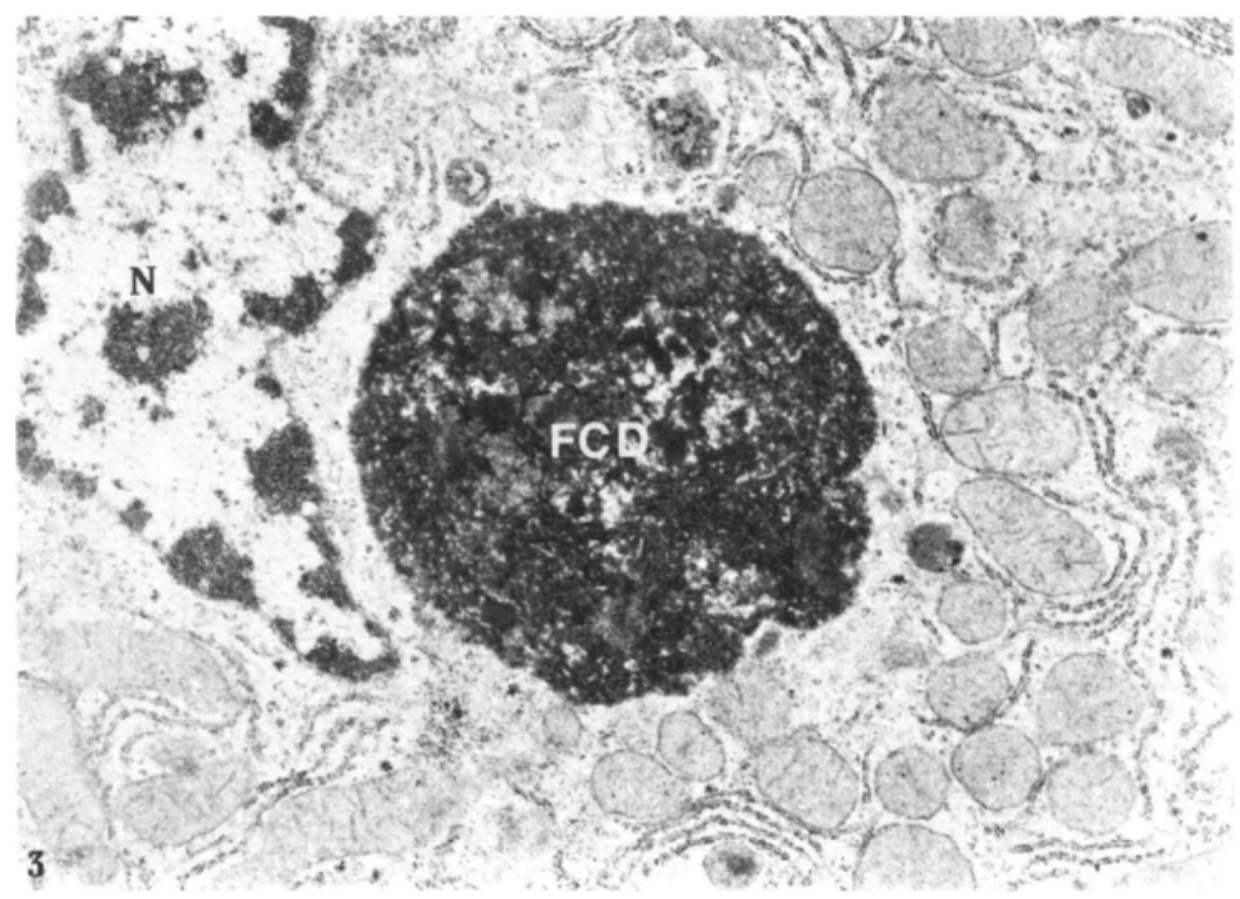

FIGURE 3. A large area of focal cytoplasmic degradation (FCD) within a hepatocyte. The FCD consisted mainly of coagulated proteins and cytoplasmic organelles. Nucleus (N). $\times 14,000$. 


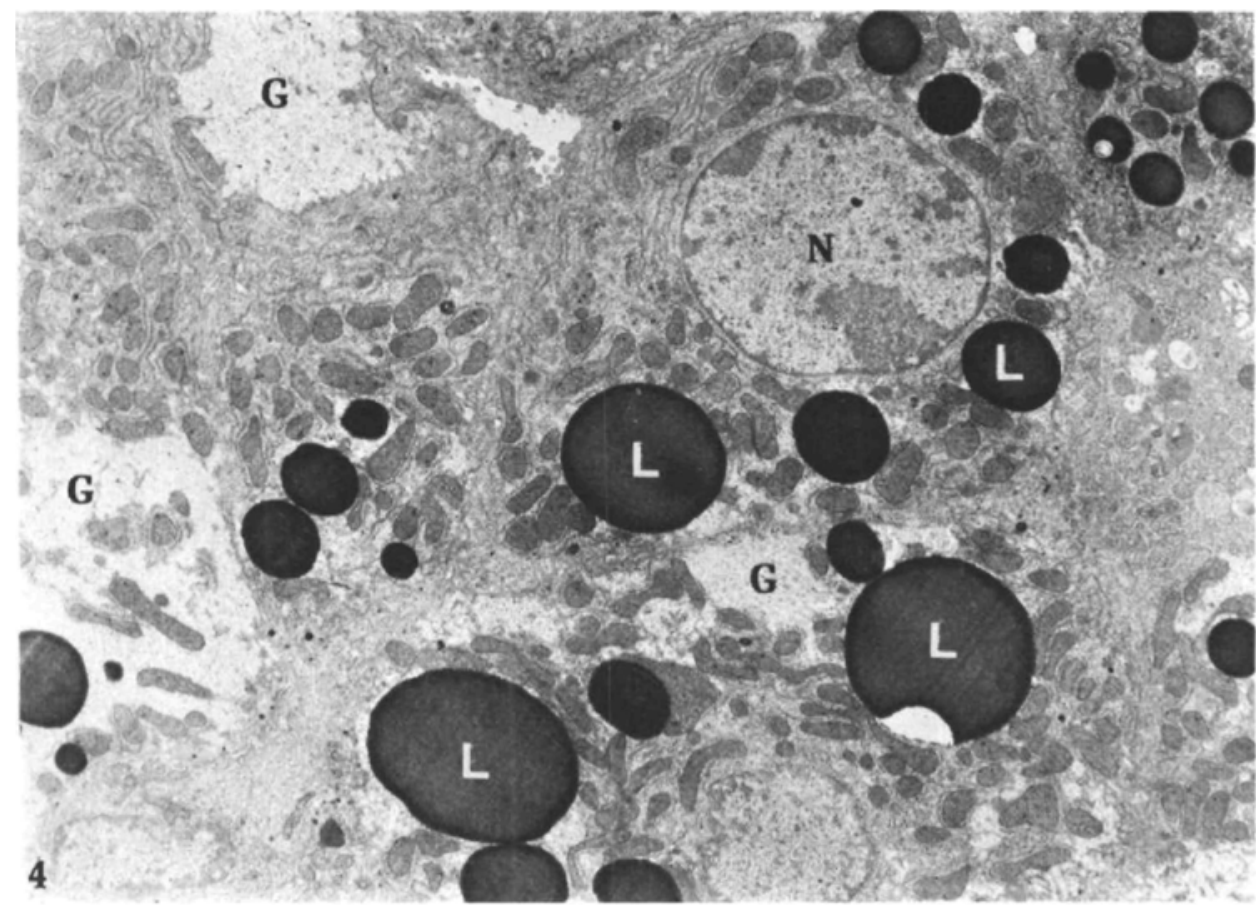

Figure 4. Accumulation of lipid droplets (L) within the hepatocytes. Nucleus (N), glycogen (G). $\times 4,800$.

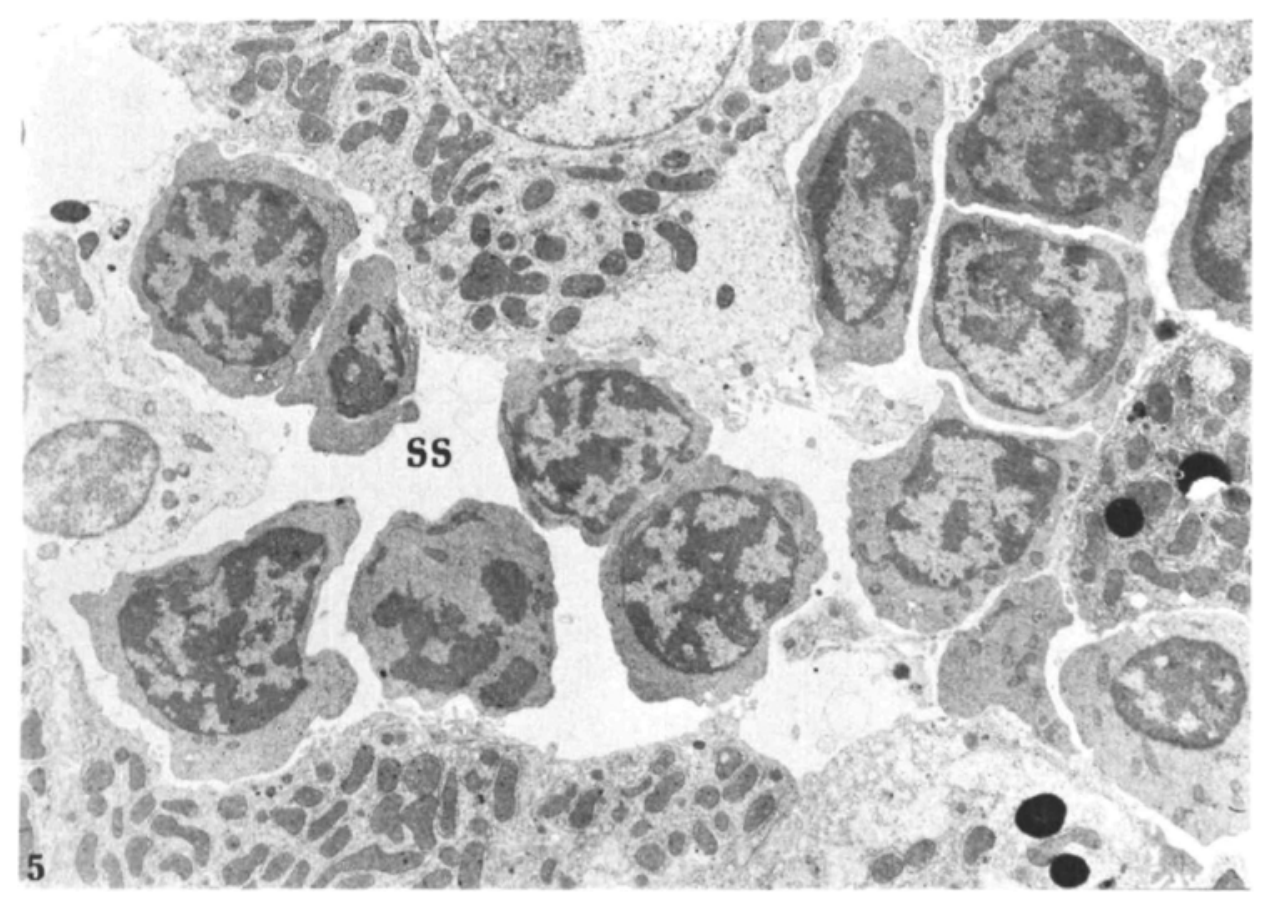

Ficune 5. Massive lymphocytic infiltration by the hepatic sinusoidal space (SS) $\times 6,500$. 


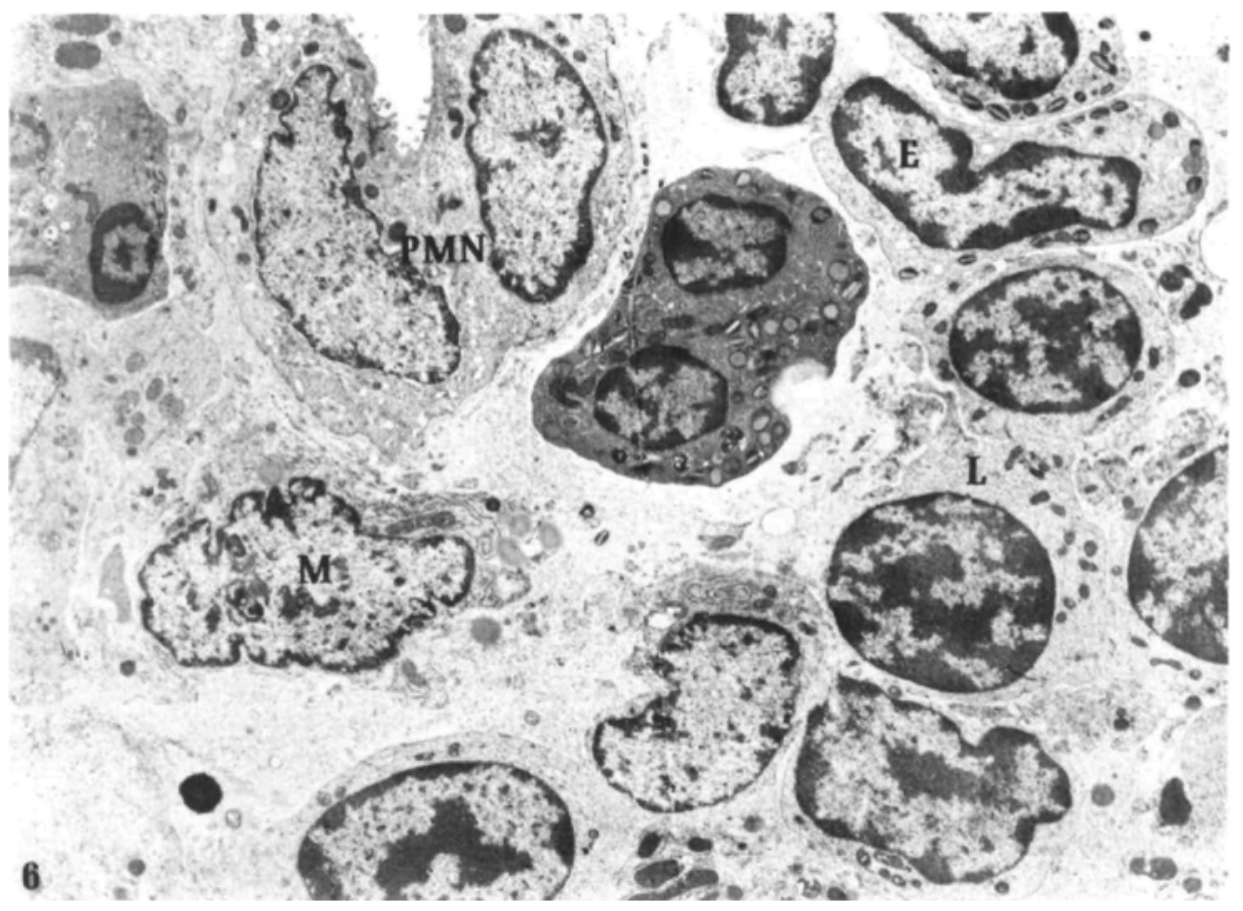

FIGURE 6. Leukocytic infiltration which consisted of lymphocytes (L), eosinophils (E), neutrophils (PMN) and macrophages $(M)$ was observed by the hepatic sinusoid. $\times 4,800$.

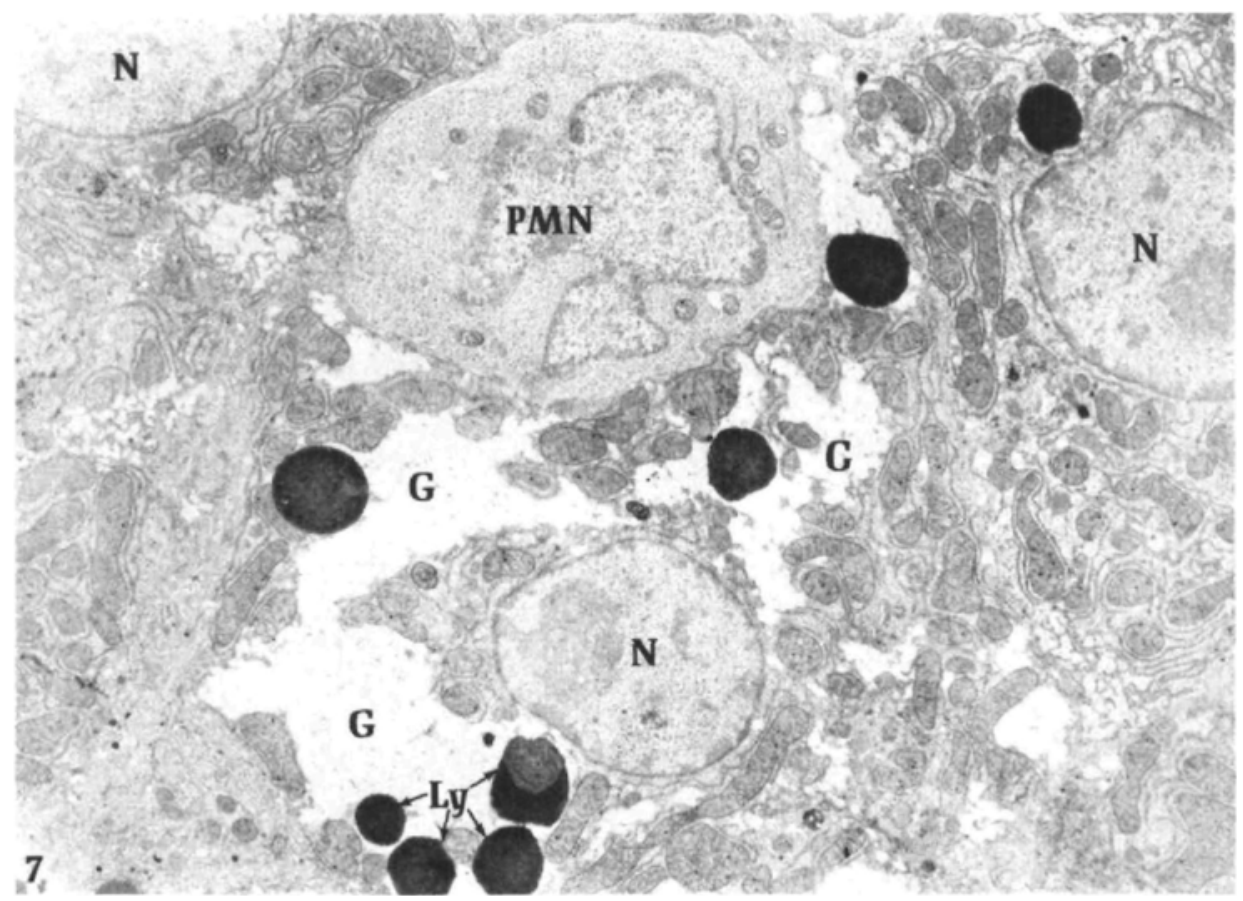

Figure 7. Infiltration of a neutrophil (PMN) into the hepatic parenchyma was observed. Accumulation of lysosomes ( Ly) was also evident in some hepatocytes. Nucleus (N), glycogen (G) $\times 6,500$. 


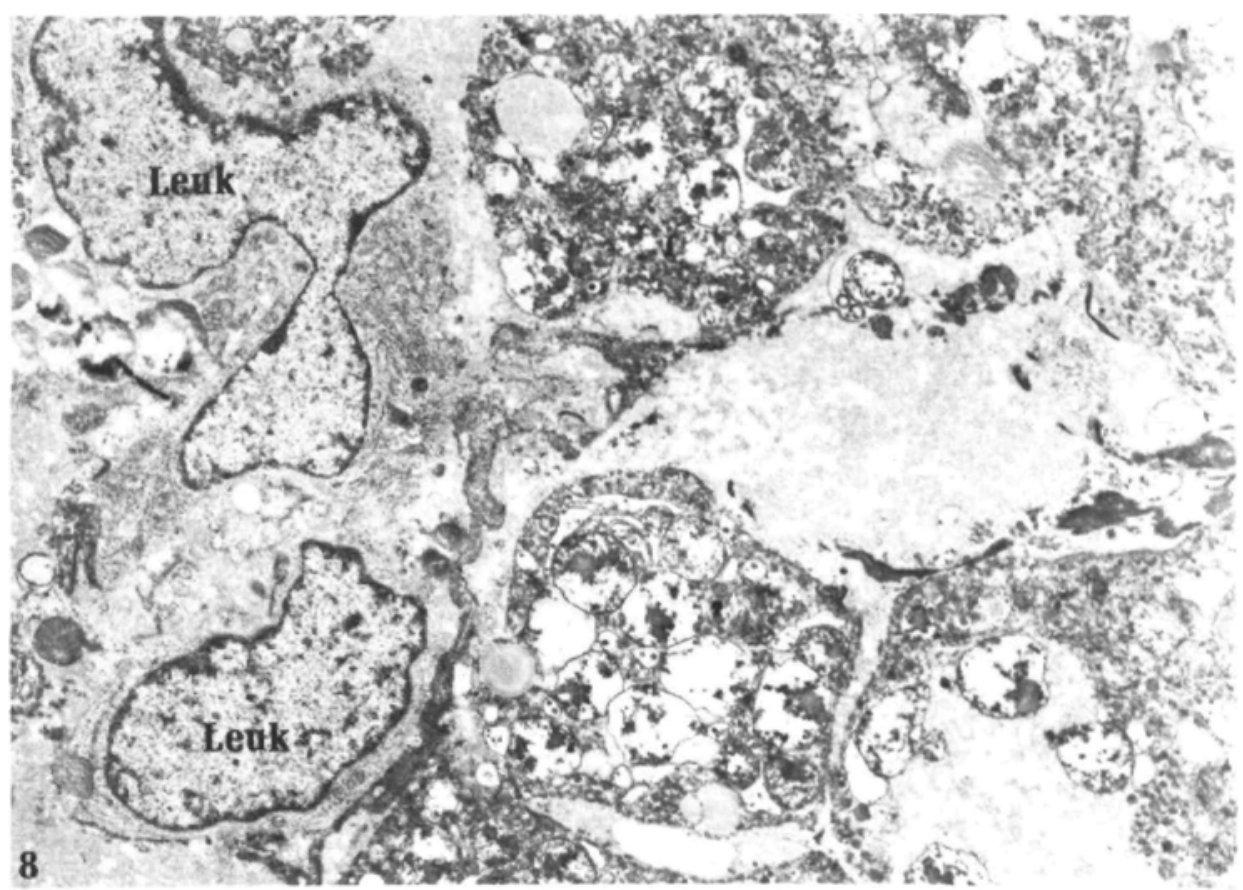

FIGURE 8. Large necrotic areas in the liver. Extensive degradation of cellular organelles and cytoplasmic materials were observed. Infiltration by leukocytes (Leuk) in these areas was also evident. $\times 6,500$.

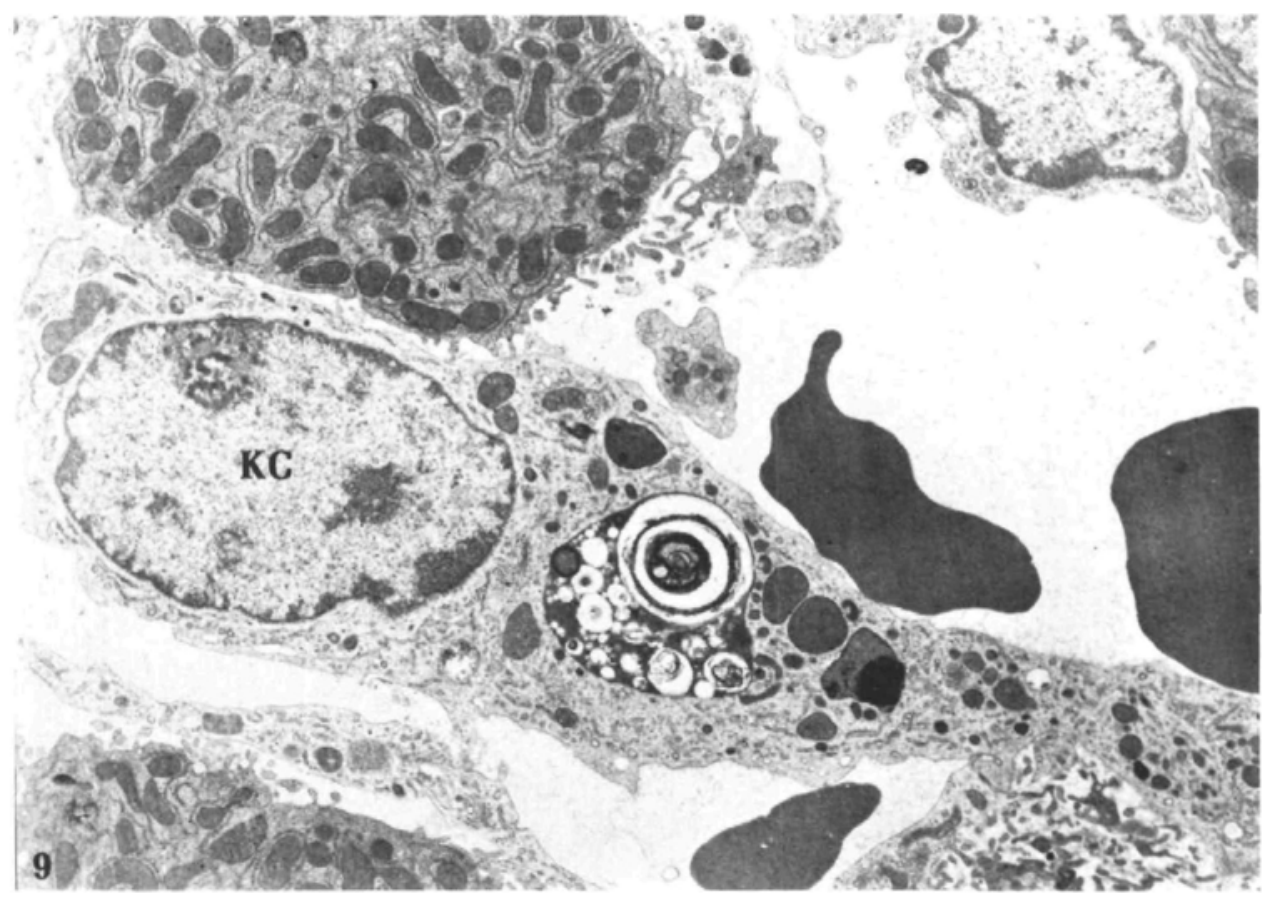

Figure 9. Removal and engulfing of cellular debris by a Kupffer cell (KC) was observed. $\times 6,500$. 


\section{Discussion}

Reports concerning post-operative hepatitis, attributed to halothane anaesthesia, began to appear shortly after $1958.28,29$ Since then, increasing alarm has been aroused by substantial numbers of cases of hepatic necrosis following the administration of halothane. ${ }^{3,30,31}$ In the recent literature, various investigators have successfully demonstrated that hepatic injury and necrosis could be induced in laboratory animals ${ }^{9,10,21}$ after either acute or chronic exposure to halothane. The hepatotoxicity of halothane has become well recognized and established. ${ }^{6}$

In the past few years, an increased occurrence of congenital abnormality, spontaneous abortion, involuntary infertility, and liver damage has been observed in association with anaesthesia, the probable cause being prolonged exposure to anaesthetics. ${ }^{11-18,32,33}$ Despite all the statistical indications that halothane could be hazardous to foetal development, the present report represents the first actual demonstration of pathological changes in the neonatal liver following in-utero exposure to trace amounts of halothane. ${ }^{9.10 .21 .26}$ Such lesions indicate various pathological and degenerative states of the hepatocytes. Massive leukocytic infiltration and active phagocytotic activity of the Kupffer cells were probably biological responses to the chronic hepatic degeneration. Although Linde and Bruce ${ }^{35}$ failed to find any histological changes at light microscopic level in adult rats which were subjected to chronic exposure to traces of halothane, the present electron microscopic investigation has demonstrated definite degenerative changes in the neonatal liver. It is possible that the foetal liver is more sensitive to halothane. Since pathological changes were also observed by means of electron microscopy in the livers of our adult animals under similar experimental conditions, ${ }^{21,26}$ ultrastructural investigation would appear to be necessary to detect some of the more subtle pathological changes.

Since the present study was designed to simulate the actual conditions of an operating room (the concentration of halothane in the ambient air of the operating room is approximately $10 \mathrm{ppm}^{13}$ ) and the average working conditions of operating room personnel ( 8 hours/day and 5 days/week), the results of the present investigation, together with those from other studies, ${ }^{18,20,22.24 .27}$ certainly suggest that halothane may be hazardous to foetal development. The human occupational hazards require further study.

\section{SUMMARY}

Eight pregnant Sprague-Dawley rates were exposed to $10 \mathrm{ppm}$ halothane 8 hours/day and 5 days/week throughout pregnancy. Liver samples were obtained from the pups for electron microscopy. Degenerative changes such as myelinfigure formation, focal-cytoplasmic degradation; fatty changes and cellular necrosis were observed. Leukocytic infiltration and phagocytosis of the cellular debris by Kupffer cells were also evident. The present investigation has demonstrated the hepatotoxic effects of halothane on the foetal liver. The role of halothane as an occupational hazard is considered. 


\section{RÉSUMÉ}

Huit rates enceintes, type Sprague-Dawley, ont été exposées à $10 \mathrm{ppm}$ d'halothane à raison de huit heures par jour et cinq jours par semaine pendant toute leur grossesse. Des échantillons de foie foetal ont été prélevées et examinées à la microscopie électronique.

Les changements dégénératifs suivants ont été notés: formation "myéline-like" dégradation cytoplasmique focale, nécrose cellulaire et dégénérescence graisseuse. Les cellules de Kupffer sont remplies de débris cellulaires et une infiltration leucocytaire diffuse a été remarquée également. Donc, cette étude montre bien les effets hépato-toxiques de l'halothane sur le foie foetal. On peut extrapoler cela en pensant au personnel de la salle d'opération (anesthésistes, infirmières, chirurgiens), qui est exposé à des concentrations semblables, durant de longues périodes de temps.

\section{REFERENCES}

1. Raventos, J. Action of Fluothane - a new volatile anaesthetic. Br. J. Pharmacol., 11: 394 (1956).

2. BARTON, J.D.M. Jaundice and Halothane. Lancet, 1: 1097 (1959).

3. BRoDy, G.L. \& SwEET, R.B. Halothane anesthesia as a possible cause of massive hepatic necrosis. Anesthesiology 24: 29 (1963).

4. Temple, R.L., Cote, R.A., \& Gorens, S.W. Massive hepatic necrosis following general anesthesia. Anesth. Analg. 41: 586 (1962).

5. Qizilbash, A.H. Halothane hepatitis. Canad. Med. Assoc. J., 108: 171 (1973).

6. Cahney, F.M.T. \& Van Dyke, R:A. Halothane hepatitis - a critical review. Anesth. Analg., $51: 135$ (1972).

7. NGaI, S.H. Hepatic effects of halothane: review of the literature. The National Halothane Study. Edited by J.P. Bunker, W.H. Forrest, F. Mosteller \& L.D. VanDam, Nat']. Inst. Hlth. and Nat'l. Inst. Gen. Med. Sci., Bethesda, Maryland, p. 11 (1968).

8. Simpson, B.R., Strunin, L., \& Walton, B. Halothane hepatitis - fact or fallacy? Bull. N.Y. Acad. Med., 49: 708 (1973).

9. Ross, W.T. \& Cardell, R.R. Effects of halothane on the ultrastructure of rat liver cells. Am. J. Anat. 135: 5 (1972).

10. Hughes, H.C. \& LANG, C.M. Hepatic necrosis produced by repeated administration of halothane to guinea pigs. Anesthesiology 35: 466 (1972).

11. Whitcher, C.E., Cohen, E.N., \& Trudell, J.R. Chronic exposure to anesthetic gas in the operating room. Anesthesiology $351: 848$ (1971).

12. Conbetr, J.H. Anesthetics as a cause of abortion. Fertility and Sterility 23: 866 ( 1972 ).

13. Jenkins, L.C. Chronic exposure to anaesthetics - a toxicity problem? Canad. Anesth. Soc. J. 20: 104 (1973).

14. Conвetr, T.H. Retention of anesthetic agents following occupational exposure. Anesth. Analg., 52: 614 (1973).

15. A.S.A. Scientific Panel: A preliminary report - the hazard of trace anesthetics in unvented operating rooms. Anesth. Rev. 1:22 (1974).

16. VAISMAN, A.I. Working conditions in surgery and their effect on the health of anesthesiologists. Ekap. Khir. Anest. 3: 44 (1967).

17. Askrog, V. \& Harvald, B. Teratogen effects of inhalation anesthetika. Nord. Med. 83: $490(1970)$.

18. Cohen, E.N., Belville, J.W., \& Brown, B.W. Anesthesia, pregnancy and miscarriage: a study of operating room nurses and anesthetists. Anesthesiology 35: 343 (1971).

19. Dudley, A.W., Jr., Chang, L.W., \& Katz, J. Ultrastructural changes in the kidney following chronic exposure to low levels of halothane. Am. J. Path. 74: 22a (1974).

20. Dudley, A.W., Jr., Chang, L.W., \& KATZ; J. Ultrastructural evidence of hepatic and renal changes in neonatal rats following in-utero exposure to low levels of halothane. Fed. Proc. 33: 625 (1974). 
21. Chang, L.W., Dudley, A.W., Jr., \& Katz, J. Ultrastructural evidence of hepatic injuries induced by chronic exposure to levels of halothane. Am. J. Path, 74: 103a (1974).

22. Chang, L.W., Dudley, A.W., Jr., Katz, J., \& Martin, A.H. Nervous system development following in-utero exposure to trace amounts of halothane. Teratology 9: A-15 (1974).

23. Chanc, L.W., Dunley, A.W., Jr., LeE, Y.K., \& Katz, J. Ultrastructural changes in the nervous system after chronic exposure to halothane. Expt. Neurol. 45: 209 (1974).

24. Quimby, K.L., Aschkenase, L.J., Bowman, R.E., KaTZ, J., \& Chang, L.W. Enduring learning deficits and cerebral synaptic malformation from exposure to $10 \mathrm{ppm}$ halothane. Science, 185: 625 (1974).

25. Chang, L.W., Dudley, A.W., Jr, Lee, Y.K., \& Katz, J. Ultrastructural changes in the kidney following chronic exposure to low levels of halothane. Am. J. Path., 78: 225 (1975).

26. Chanc, L.W., Dudlex, A.W., Jr., Lee, Y.K., \& Katz, J. Ultrastructural studies of the hepatocyte following chronic exposure to low levels of halothane. Exp. Mol. Path., (August), (1975).

27. Chang, L.W., Dudley, A.W., Jr., Lee, Y.K., \& Katz, J. Ultrastructural study on the neonatal kidney after in-utero exposure to halothane. Environ. Res. (in press) (1975).

28. Burnap, T.K., Galla, S.J., \& VanDam, L.D. Anesthetic, circulatory and respiratory effect of fluothane. Anesthesiology 19: 307 (1958).

29. Vintue, R.N., Payne, K.W., \& Caranna, L.J. Observation during experimental and clinical use of fluothane. Anesthesiology 19: 478 (1958).

30. Bunker, J.P. \& Blumenfeld, C.M. Liver necrosis after halothane anesthesia: cause or coincidence? N. Eng. J. Med. 268: 531 ( 1963 ).

31. Lindenbaum, J. \& Leifer, E. Hepatic necrosis associated with halothane anesthesia. N. Eng. J. Med. 268: 525 (1963).

32. Corbetr, T.H. Birth defects among children of nurse anesthetists. Anesth. Rev, 1: 23 (1974).

33. Gotell, P. \& Sundell, L. Anaesthetists' exposure to halothane. Lancet 1: 424 (1972).

34. Linde, H.W. \& Bruce, D.L. Effects of chronic exposure of rats to traces of halothane. Progress in Anesthesiology, Excerpta Med. Int. Cong, Serial No. 200: 923 (1968). 